\title{
The Jamesonian Impersonal; or, Person as Allegory
}

\author{
Daniel Hartley | ORCID: 0000-0002-3290-7251 \\ Assistant Professor, Department of English Studies, \\ Durham University, Durham, UK \\ daniel.j.hartley@durham.ac.uk
}

\begin{abstract}
This article locates Fredric Jameson's Allegory and Ideology (2019) in the context of the broader trajectory of his career-long critique of the bourgeois centred subject. It argues that, for Jameson, the project of critique requires systematic depersonalisation at the level of thought. Contrary to negative liberal humanist interpretations of depersonalisation, Jameson stresses its hidden, revolutionary potential. Where his earlier work eschewed metanarratives of modernity premised upon shifts in subjectivity, preferring conjunctural or situational analyses, his more recent work - Antinomies of Realism (2013) and Allegory and Ideology in particular - develops a materialist version of just such metanarratives. The article concludes with a detailed application of Jameson's allegorical method to the figure of the 'person' under capitalism, which can be sub-divided into the four levels of: individual, citizen/juridical person, infrastructural personifications, and the realm of social reproduction.
\end{abstract}

\section{Keywords}

Jameson - allegory - personhood - depersonalisation - impersonality - social reproduction - citizenship - realism

It would be tempting, indeed, to go on to show

how even the forms of modern literary criticism are unable to evade the dynamic of depersonalisation.

FREDRIC JAMESON, A Singular Modernity 
The 'person', viewed negatively, is the experiential corollary of reification: the lived modality of the monad amidst the alien tundra of capital's second nature. For Fredric Jameson, the cultural dominance of the personal under capitalism is precisely that which prevents the re-imagination of a collective revolutionary horizon, or which serves (ideologically and representationally) to re-contain the latter's periodic resurgence within 'the privacy and elbowroom of Western middle-class society'. In 'Third-World Literature in the Age of Multinational Capitalism' - reprinted in Allegory and Ideology - a strict division between the personal, private realm and the public world is associated with the fully capitalist nation-states of the then First World, imbuing Jameson's critique of the 'mirage of the "centred subject" and the unified personal identity' with an anti-imperial edge. ${ }^{2}$ (It will be recalled that it is precisely the lack of this clear split between private and public in the partially capitalised states of the then Third World that was said to generate 'national allegories': the representational result of the structural overdetermination of the personal by the political.) One of the implicit and persistent presuppositions of Jameson's work is that critique, which itself presupposes a sense of historicity and collective political possibility, requires systematic depersonalisation at the level of thought. It is this presupposition, along with the style in which he has forged it, that I refer to as the Jamesonian impersonal. ${ }^{3}$

The flipside of such critique is a dialectical transvaluation of the very notion of 'depersonalisation', a brief account of which may prove useful in setting out the larger problematic of which Allegory and Ideology is the most recent iteration. If from a liberal humanist perspective 'depersonalisation' signals authoritarianism or some privative and humanly-diminishing force, Jameson reveals its hidden radical or representational potential. Writing on modernist impersonality in A Singular Modernity (2002), for instance, Jameson explains he wants to show

1 Jameson 1971, p. 305.

2 Jameson 2019, p. 161.

3 For an account of Jameson's theory of style, see Hartley 2017; on Jameson's own style, see Eagleton 2009. 
everything that is energizing and active about a depersonalizing tendency that has too often been discussed in terms of loss and incapacitation; in demonstrating how such a renunciation of subjectivity, far from amounting to some resignation to an impossibly 'alienating' condition, stands on the contrary as an original and productive response to it. ${ }^{4}$

Drawing on Perry Anderson's 'Modernity and Revolution' (1984), Jameson reads 'the great modernist evocations of subjectivity' not as symptoms of the muchtouted modernist 'inward turn' but rather as 'allegorical of the transformation of the world itself, and therefore of what is called revolution': 'a longing for depersonalization, and very precisely for some new existence outside the self, in a world radically transformed and worthy of ecstasy. ${ }^{5}$ Allegory here names the mediating process by which (objective) revolutionary change is transposed into (subjective) figures of transformation. The model is Sartre's account of the gravitational 'action at a distance' effected by the Marxist masses upon the petit-bourgeois intellectual, but one might also think of Kant, Hegel, and the early Marx faced with the spectacle of the French Revolution - the emergent deutsche Misère now recast as allegorical figuration and frustration.

Yet here we encounter a problem of which Jameson himself is well aware. The virtue of Anderson's account is that it is conjunctural - and it was Jameson's conscious decision in A Singular Modernity to adopt a conjunctural approach (though he prefers the Sartrean term 'situation') to modernism as opposed to reproducing the myriad ideological metanarratives of modernity's emergence. The third of Jameson's four 'maxims of modernity' reads: 'The one way not to narrate [modernity] is via subjectivity (thesis: subjectivity is unrepresentable). Only situations of modernity can be narrated. ${ }^{6}$ The dangers of narratives premised upon subjectivity are evident. Either modernity becomes an idealist tale of the rise of freedom, individuality and self-reflexivity, or a mournful narrative of Spenglerian decline, Weberian disenchantment, or some more pervasive 'alienation'. Jameson has always opted for a situational approach in which each 'situation' is, at its limit, coextensive either with a given mode of production or, more commonly, with a particular stage of development of a given mode of production (e.g., his work on the rise and decline of modern style can roughly be narrated thus: market capitalism-realism-rhetoric, monopoly capitalismmodernism-style, late capitalism-postmodernism-styleless-ness). Each stage constitutes a situation with a unique 'cultural dominant' that any literary or

4 Jameson 2002, pp. 132-3; my emphasis.

5 Jameson 2002, p. 136.

6 Jameson 2002, p. 94. 
artistic production must negotiate as it sees fit. ${ }^{7}$ The strength of this approach is that it allows the critic to reconstruct a whole range of different cultural productions as 'responses' to a single situation, and in doing so to imbue them with the proactivity of a gesture or an act. The problem - both theoretical and representational - then becomes how one conceives of transitions from one situation (or mode of production) to the next without falling back into idealist metanarratives.

Jameson's elegant solution to this problem has always been 'cultural revolution' (indeed, the chapter dedicated to the topic in Valences of the Dialectic (2009) reads like a set of preparatory notes for a book one hopes Jameson will one day write). At any one moment, several modes of production coexist structured in dominance - in a social formation: ancient relics and Utopian prefigurations rustle and stir amidst the dull compulsion of the capitalist value-form. 'Cultural revolution' names the moment at which this coexistence becomes openly antagonistic - the Enlightenment as bourgeois cultural revolution being Jameson's principal case in point. What Jameson's recent work offers is, then, something akin to a series of miniature studies of the effects of cultural revolution on literary production and subjectivity (like Günter Grass, he is 'a miniaturist, albeit a maximalist one'). ${ }^{8}$ It is here that his situational conception of modernist depersonalisation gives way - in line, perhaps, with cultural revolution being itself a dynamic, diachronic process - to a narrative of modern depersonalisation. That is, Antinomies of Realism (2013) and Allegory and Ideology (2019) harbour precisely those metanarratives of subjectivity that it was previously Jameson's express wish to avoid - though they are anything but conventional (and anything but idealist). ${ }^{9}$

Antinomies of Realism tells the story of a gradual process of literary depersonalisation from realism (a delicate balance of récit and affect) to modernism (affect's victory): from Zola's characters who become 'the most perfunctory pretexts for what is virtually an autonomous unfolding of sense data, ${ }^{10}$ through Tolstoy's restless shifts in mood in which the true characters become the very affects - and their variations - themselves, on through the waning of protagonicity in Galdós (whereby putative heroes and heroines recede into the background and give way to 'minor' or 'secondary' characters), to George Eliot whose invention of mauvaise foi avant la lettre narratively deconstructs the

Jameson 1981, p. 6.

Jameson 2019, p. 320 .

It should be noted that Jameson is well aware of this - citing his own previous warnings regarding narratives of subjectivity from A Singular Modernity. Jameson 2019, p. 71, n. 26.

Jameson 2013, p. 59 . 
ethical binary of Good and Evil that is the ultimate ideological habitat of the 'personal'. In a quite astonishing manoeuvre, then, Jameson pulls the ideological rug from under us. For it is not simply that the now-mythical 'bourgeois individual' (of whom sightings are as rare as of the Loch Ness monster) eventually succumbs to 'the death of the subject' in postmodernity: it turns out that the bourgeois subject never existed in the first place! Jameson has chased it out even of the very locus classicus it was said representationally to inhabit: the realist novel itself. The new hegemony of 'everyday life' with its anti-heroic tendencies and temporalities, and the rise of a general consciousness of universal claims to social equality are said to exert a depersonalising pressure upon the characterological fabric of the novel. Jameson effectively hollows out the oncefêted bourgeois individual, leaving only the husk of a 'character's name and place in the action'.11

The reader of Allegory and Ideology is then somewhat surprised to learn that many of the qualities associated with the 'bourgeois individual' - e.g., interiorised subjectivity and self-consciousness - have been rediscovered elsewhere: not in nineteenth-century Paris or London, but all the way back in the Roman Empire! In a majestic reconstruction of the social life-worlds from which the respective emotional systems of the Greek polis and the Roman Empire are said to have emerged, Jameson locates the origins of the 'construction of subjectivity' in the universal Empire itself - with its vast, culturally diverse populations whose subjects are said to enjoy a 'kind of equality' 'in the face of that lone supreme Subject who is the emperor (until his structural place is taken by God himself).'12 Like some pan-imperial panopticon - signalling a Sartrean twist on Foucauldian themes (surveillance, Christian care of the self, population) - this 'omnipresent Other ... permits a new kind of introspection' that inspires a codification of the emotions as sins for the first time. ${ }^{13}$ Yet precisely because of the imperial context comprising vast class and cultural diversity, the formulation of this internal space becomes an allegorical figuration of the external spaces of empire: 'a systemic review of social positions linking characterology with external class and geographical (ethnic) positions.' ${ }^{14}$ Jameson then reads this shift from the limited dynamics of the Greek polis to the scale of the Roman empire as analogous to our 'contemporary supersession of the national by globalization. ${ }^{15}$

\footnotetext{
11 Jameson 2013, p. 84.

12 Jameson 2019, pp. 70-1.

13 Jameson 2019, pp. 78-9.

14 Jameson 2019, p. 79.

15 Ibid.
} 
When faced with arguments of such dizzying epic scope, one has to allow for a certain strategic use of exaggeration and simplification (not quite Adorno's ' $[\mathrm{i}] \mathrm{n}$ psychoanalysis nothing is true except the exaggerations', but not far off it). In his classic pincer-movement, Jameson undermines the unity of the individual subject from within (deconstructing it into so many emotions or affects) and without (rewriting the individual as an allegorical figuration of a collective system). If Antinomies of Realism told the story of the transition to modern(ist) depersonalisation, Allegory and Ideology narrates 'the disappearance of personification that signals the emergence of modernity': ${ }^{6}$ the (bourgeois) 'person', which should logically be situated between the end of one narrative and the start of the next, is then nowhere to be found - a vanishing mediator. ${ }^{17}$ If for Derrida it is always too late to talk about time, for Jameson it is always too late (or too early!) to talk about the 'centred subject'. ${ }^{18}$ Instead, the book develops a theory of subject formation as a process of naming and reification (most powerfully in the chapter on Spenser), in which some internal affective, psychic raw material is (re)organised into a named 'system of nouns and substantives': 'a blind groping about the informe, the inchoate, the primal and unorganized, with a view to separating its masses of heterogeneous materials, collecting them, designating them with a name and identification.' ${ }^{19}$ As in Gramsci's notion of the persona, a discontinuous composite of 'prejudices from all past phases of history at the local level and intuitions of a future philosophy, ${ }^{\prime 20}$ the inner life of the Jamesonian subject is a decentred amalgam of residual and emergent emotional systems and affective fluctuations. Likewise, it is always overdetermined by 'laterality' and 'transversality' - those discontinuous intersections between the various allegorical levels, whose isotopie (in this case, the allegorical precondition of the centred subject) is never assured.

\footnotetext{
$16 \quad$ Jameson 2019, p. 48.

17 It is not coincidental that Jameson's arguably most-sustained engagement with the category of 'personality' comes in the very essay 'The Vanishing Mediator' itself, with its virtuoso account of Weber's personality-formation. See Jameson 2008, pp. 309-43.

18 Even in the now-canonical chapter on Balzac in The Political Unconscious we discover 'a psychic situation in which the centred subject has not yet emerged'. Jameson 1981, p. 179 .

19 Jameson 2019, p. 243.

$20 \quad$ Gramsci 1971, p. 324.
} 
Given Jameson's justifiable antipathy to liberal notions of 'personhood', it may now come as something of a surprise if I suggest that his fourfold allegorical method enables us to map the allegorical structure of personhood under capitalism. That is, rather than agree or disagree with this or that reading in Allegory and Ideology - the vast sweep of which only he would dare (from the Greek polis to postmodernity) - it seems to me more productive to honour Jameson's own penchant for the Brechtian Nützliches (what he elsewhere calls that 'garage space in which all kinds of machinery can be tinkered with and rebuilt' $)^{21}$ by putting this particular bit of theoretical kit to use. We can begin by noting that the very concept of the 'person' bears within it traces of a range of previous cultural revolutions. Marcel Mauss charted its trajectory from the tribal 'role' (limited in number) to the Roman persona - a mask or character in a dramatic play, or a legal subject entitled to the inheritance of an estate (only the pater familias qualified as a 'person') - via the Stoics and Christians to the modern bourgeois person who is said to be 'conscious, independent, autonomous, free and responsible'. ${ }^{22}$ (Mauss even mentions the tantalising possibility that the revolt of the plebs was decisive in the universalisation of the status of persona beyond the privileged patres familias. ${ }^{23}$ In modern times, the concept hovers between two meanings: a social role unconnected to subjective interiority (as in Hobbes) and the self-conscious 'moral person' (as in Locke and Kant). Jameson's method allows us to sublate this duality and reconstruct the 'person' as a fourfold allegory, which we shall map onto a Greimasian square (see Figure 1) in line with Jameson's suggestive claim that there exists some secret affinity between the square and the structure of allegory itself. ${ }^{24}$

I shall argue that each of the four levels of the 'person' is centred upon one or more 'figures of subjectivity': sites of struggle between subjection and subjectivation..$^{25}$ For though I agree in many respects with Jameson's narrative of modern depersonalisation, my own account would emphasise its dialectical complement: the continued centrality of a set of structural personae that are

\footnotetext{
21 Jameson 2005, p. 14.

22 Mauss 1985.

23 Mauss 1985 , p. 16.

24 I am grateful to Natalya Bekhta and Gero Guttzeit for their help in plotting this particular Greimasian square.

25 I am drawing here on Sandro Mezzadra, the subtitle of whose book In the Marxian Workshops: Producing Subjects is obviously relevant to Jameson's notion of the 'construction of subjectivity'. See Mezzadra 2018.
} 
Liberal Subject

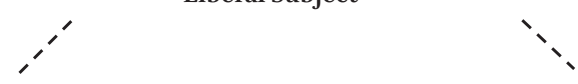

INDIVIDUAL

Existential

Flesh-and-blood

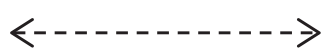
JURIDICAL PERSON
Citizenship
Border regimes
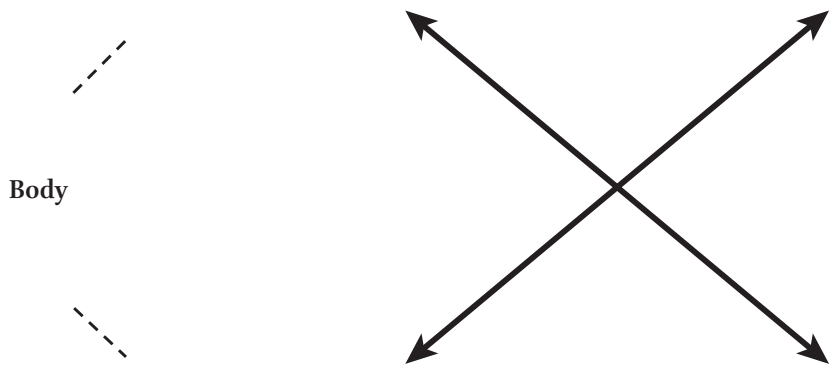

SOCIAL REPRODUCTION

Friendship/ family

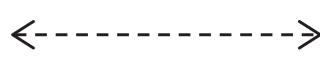

Care work

Illegal immigrants

Surplus population
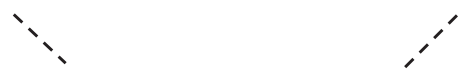

\section{INFRASTRUCTURAL PERSONIFICATIONS}

Economy:

Capital versus

Labour-power

Value form versus

order of the person

Comrade

FIGURE 1 The 'person' under capitalism

intrinsic to capital accumulation. ${ }^{26}$ Let us begin with the contraries, adapted from Jameson's distinction in 'Third-World Literature': personal and public. We shall call the former 'individual': the personal, private and intimate realm. It is the existential modality of the flesh-and-blood human being - the hoping, dreaming, anxious, suffering individual of whose life Che Guevara once declared that it is worth 'millions of times more than all the property of the richest man on earth'. Conceptually speaking, it denotes (to adopt a more technical jargon) the individuated instance of a given 'differential form of historical individuality' - i.e., all individuals are transindividual constructions (even

26 I should note that my focus here is on so-called 'Western' (or formerly 'First World') social formations. I have considered the dynamics of personhood in postcolonial social formations in Hartley 2019b. 
here, we seek to avoid the liberal humanist temptation). ${ }^{27}$ Yet ultimately it also names something like a political and representational demand: the urgent reality that cries out to be seen and heard beyond all the veils of ideology, the layers of reified response and the limitations of existing cultural forms.

Its contrary is then the collective world of the public, which we may transcode as the arena of interpellation. ${ }^{28}$ (It is perhaps not coincidental that recent work on interpellation has suggested we understand it as a process of personification. $)^{29}$ Marx's 'On the Jewish Question' will serve as our guide here, for it was precisely his argument that modern nation-states internally divide their subjects into man (l'homme) - 'the real man ... in his sensuous, individual, and immediate existence' - and the citizen (le citoyen), which he tellingly describes as 'simply abstract, artificial man, man as an allegorical, moral person', i.e., as one of Jameson's 'bad' allegories. ${ }^{30}$ Given Jameson's propensity to warn against the desire for unification, ${ }^{31}$ we note with interest that it was Marx's aim at this time to sublate the allegorical division between civil and political society: 'Only when real, individual man resumes the abstract citizen into himself ... will human emancipation be completed. ${ }^{32}$ The primary subjective figure of this level is thus that of the citizen, but as no end of 'humanitarian' disasters have since reminded us, it is intimately bound up with the correlative figure of the rights-bearing juridical person (which developed as the legal counterpart to the commodity-form, as Pashukanis famously argued). ${ }^{33}$ It fell to Arendt to articulate the fatal aporia of the man-citizen binary: "The Rights of Man, supposedly inalienable, proved to be unenforceable ... whenever people appeared who were no longer citizens of any sovereign state. ${ }^{34}$ This level is thus the site of all those struggles over citizenship ('the right to have rights'), legal rights, national identity, border regimes and autonomous mobility.

Yet just as Marx in Capital invokes the Dantean katabasis, descending from the veritable Eden of equal rights into the inferno of the hidden abode of production, so must we, in our Greimasian square, descend from the luminous

27 Cf. Balibar 2015b, p. 417, and Sève 2015 .

28 Albeit I heed Althusser's warning that it is the capitalist state itself that determines the precise distribution of public and private.

29 See Balibar 2015a and Lecercle 2019.

$30 \quad$ Marx 1975, p. 234.

31 See, for example, his rejection of Gramsci's defence of the total unity of Canto X of Dante's Inferno against Croce's critique. Jameson 2019, pp. 263-4.

$32 \quad$ Marx 1975, p. 234.

33 Pashukanis 1978.

34 Arendt 2004, p. 372. On the narrative implications of Arendt's conception of the legal person, see Hartley 2o19a. 
realm of the citoyen to the shadowy underworld of the Charaktermasken. This is the realm of work and the economy in which the empirical individual and juridical person give way to what we might call infrastructural personifications: those points in the system at which the fundamental social relations of production are concentrated and imposed - like an iron mask - upon subjective 'bearers' (Träger). '[T] he characters who appear on the economic stage [die ökonomischen Charaktermasken der Personen]', writes Marx, 'are merely personifications of economic relations; it is as the bearers of these economic relations that they come into contact with each other. ${ }^{35}$ The section of the Grundrisse entitled 'Forms which precede capitalist production' reads like a veritable summa of the various pre-capitalist permutations of such personifications, but the pair that concerns us here is: capital and labour-power. These are the twin figures that the capitalist valorisation process produces and presupposes; they are the outcome of that deeply allegorical process known as 'alienation', which combines the separation of living labour from the objective conditions of labour with the personification of those conditions in the person of the capitalist - 'a personification with its own will and interest'. ${ }^{36}$ In the process, the worker becomes herself internally divided between two corporeal and existential tendencies. ${ }^{37}$ Capital posits the worker as an unaccommodated body, a mere repository of labour-power separated from all that sustains life (Spenser's Malbecco, in whom 'the concentration of the mind on a single emotion has wasted the rest of the human substance', now stands as a prefiguration of the worker possessed by capital's unremitting zeal). ${ }^{38}$ Meanwhile, the worker posits herself as an inherently meaningful person with a rich and variegated inner life engaged in any number of relationships and life projects. This is one of the fundamental contradictions of capitalist societies: the struggle between the capitalist law of value and what Lucien Sève has named the 'order of the person', his ingenious term for what we might call an anti-capitalist law of value: the 'value form inherent to each human being' (not, incidentally, some idealist abstraction - as Marx criticised in the sixth thesis on Feuerbach - but the hard-won, accumulated common sense of what Raymond Williams would call 'the long revolution'). ${ }^{39}$

This now leaves some hazy fourth level whose very obscurity is symptomatic of its marginalisation in capitalist societies. I shall call it the level of social

\footnotetext{
$35 \quad$ Marx 199o, p. 179.

$36 \quad$ Marx 1973, p. $45^{2}$.

37 I have expanded upon this idea in Hartley 2018.

38 Jameson 2019, p. 237.

39 Cf. Sève 2oo6, pp. 51-6.
} 
reproduction: the realm of care work, domestic labour, the family, friendship, and work beyond the zone of commodification. It is well known that in addition to extinguishing the phenomenal distinction between necessary and surplus labour, the wage-form also extinguishes the role of unwaged labour in the valorisation process. Marxist feminists, as in the 'Wages for Housework' movement, have struggled against this devaluation of what remains primarily women's work (including within the Marxist tradition itself). Yet the logic of the square suggests that they are also structurally related to the categories of 'non-citizen' and 'non-juridical person', thus immediately bringing into view (in some Jamesonian anagnorisis) a vast hinterland of 'illegal immigrants', migrant workers, labourers in the 'informal economy', 'surplus populations', the 'reserve army of labour', and refugees. It is telling indeed that this level, unlike its three predecessors, fails easily to coalesce around a single figure of subjectivity: under capitalism, it seems, the only thing worse than being personified is not being personified. Its most typical figure (in a nigh-on Lukácsian sense) would perhaps be the migrant woman care-worker: socially reproducing 'Western' subjects, on the margins of the formal economy, ever at the mercy of racist border regimes. ${ }^{40}$

Such, then, is one possible rendering of the allegorical structure of the person under capitalism. There is no space here to flesh out the combinatory terms (liberal subject, professional 'role', comrade, body), nor is there room to explore the ways in which social forms such as gender and race are imbricated with various 'transversal' combinations (or mutual exclusions) of the respective levels (not to mention the possible rearticulation of the levels in spatial or literary terms). I shall conclude simply by observing that, in line with Jameson's emphasis on heterogeneity and differences that relate, the square captures something of the discontinuous lived experience - the 'undisambiguated synonymity' 41 - of capitalist societies: the multiple subjective planes on which we make ourselves and are, in turn, made. It also implies the necessity for some form of coordination across levels in any radical politics worthy of the name. Just as Gramsci was deeply concerned with questions of translation between languages and contexts - not least (following Lenin) the translatability of the Russian Revolution into European countries whose social formations were utterly distinct - so we might rewrite the productive notions of 'transversality' and 'laterality' as conscious efforts to connect subjective figures and sites of struggle. In such a scenario, allegory - like Gramsci's 'democratic

Albeit, via 'femonationalism', women migrant-workers fare better than their male counterparts under neoliberal regimes. See Farris 2012.

41 Jameson 2019, p. 332. 
philosopher' - would name a collective power of self-organisation and selfeducation whose ultimate horizon is proletarian cultural revolution.

\section{References}

Althusser, Louis, Étienne Balibar, Roger Establet, Jacques Rancière and Pierre Macherey 2015, Reading Capital: The Complete Edition, translated by Ben Brewster and David Fernbach, London: Verso.

Arendt, Hannah 2004 [1951], The Origins of Totalitarianism, New York: Schocken Books. Balibar, Étienne 2015a, 'Althusser's Dramaturgy and the Critique of Ideology', differences: A Journal of Feminist Cultural Studies, 26, 3: 1-22.

Balibar, Étienne 2015b [1965], 'On the Basic Concepts of Historical Materialism', in Althusser, Balibar, Establet, Rancière and Macherey 2015.

Eagleton, Terry 2009, 'Jameson and Form', New Left Review, II, 59: 123-37.

Farris, Sara R. 2012, "Femonationalism and the "Regular" Army of Labor Called Migrant Women', History of the Present, 2, 2: 184-99.

Gramsci, Antonio 1971, Selections from the Prison Notebooks, edited and translated by Quintin Hoare and Geoffrey Nowell-Smith, New York: International Publishers.

Hartley, Daniel 2017, The Politics of Style: Towards a Marxist Poetics, Historical Materialism Book Series, Leiden: Brill.

Hartley, Daniel 2018, 'The Aesthetics of Non-Objectivity: From the Worker's Two Bodies to Cultural Revolution', Studi di estetica, IV, 18: 137-50.

Hartley, Daniel 2019a, 'Home and Law: Impersonality and Worldlessness in J. M. Coetzee's The Childhood of Jesus (2013) and Jenny Erpenbeck's Gehen, Ging, Gegangen (2015)', in Refugee Imaginaries: Research Across the Humanities, edited by Emma Cox, Sam Durrant, David Farrier, Lyndsey Stonebridge and Agnes Woolley, Edinburgh: Edinburgh University Press.

Hartley, Daniel 2019b, 'The Person, Historical Time and the Universalisation of Capital', Salvage, 2 April, available at: <https://salvage.zone/in-print/the-person -historical-time-and-the-universalisation-of-capital/>, accessed 23 April 2020.

Jameson, Fredric 1971, Marxism and Form: 2oth-Century Dialectical Theories of Literature, Princeton, NJ: Princeton University Press.

Jameson, Fredric 1981, The Political Unconscious: Narrative as a Socially Symbolic Act, Ithaca, NY: Cornell University Press.

Jameson, Fredric 2002, A Singular Modernity: Essay on the Ontology of the Present, London: Verso.

Jameson, Fredric 2005, Archaeologies of the Future: The Desire Called Utopia and Other Science Fictions, London: Verso.

Jameson, Fredric 2008, The Ideologies of Theory, Updated Edition, London: Verso. 
Jameson, Fredric 2013, The Antinomies of Realism, London: Verso.

Jameson, Fredric 2019, Allegory and Ideology, London: Verso.

Lecercle, Jean-Jacques 2019, De l'interpellation: sujet, langue, idéologie, Paris: Éditions Amsterdam.

Marx, Karl 1973, Grundrisse: Foundations of the Critique of Political Economy (Rough Draft), translated by Martin Nicolaus, Harmondsworth: Penguin.

Marx, Karl 1975 [1843-4], Early Writings, translated by Rodney Livingstone and Gregor Benton, Harmondsworth: Penguin.

Marx, Karl 199o [1867], Capital: A Critique of Political Economy. Volume One, translated by Ben Fowkes, London: Penguin Classics.

Mauss, Marcel 1985 [1938], 'A Category of the Human Mind: The Notion of the Person; the Notion of the Self', translated by W.D. Halls, in The Category of the Person: Anthropology, Philosophy, History, edited by Michael Carrithers, Steven Collins and Steven Lukes, Cambridge: Cambridge University Press.

Mezzadra, Sandro 2018 [2014], In the Marxian Workshops: Producing Subjects, translated by Yari Lanci, London: Rowman \& Littlefield.

Pashukanis, Evgeny 1978, Law and Marxism: A General Theory, edited by Chris Arthur, translated by Barbara Einhorn, London: InkLinks.

Sève, Lucien 2006, Qu'est-ce que la personne humaine? Bioéthique et démocratie, Paris: La Dispute.

Sève, Lucien 2015, Pour une science de la biographie; suivi de Formes historiques d'individualité, Paris: Les Éditions Sociales. 